\title{
STATUS PEMANFAATAN SUMBERDAYA IKAN DEMERSAL DI DUMAI, RIAU
}

\author{
Status of demersal fish resources utilization in Dumai , Riau
}

\author{
Oleh: \\ Muhammad Nur Arkham ${ }^{1}$, Perdana Putra Kelana ${ }^{1 *}$, Tyas Dita Pramesthy ${ }^{1}$, Djunaidi ${ }^{1}$, \\ Sri Yenica Roza ${ }^{1}$, Suci Asrina Ikhsan ${ }^{1}$ \\ ${ }^{1}$ Program Studi Perikanan Tangkap, Politeknik Kelautan dan \\ Perikanan Dumai, Dumai, Indonesia \\ *Korespondensi penulis: perdana.pk@politeknikkpdumai.ac.id
}

\begin{abstract}
ABSTRAK
Kota Dumai memiliki nelayan perikanan tangkap skala kecil yang menjadikan ikan demersal sebagai target utama. Daerah penangkapan ikan demersal yang relatif mudah dan dekat untuk diakses serta memiliki milai ekonomis yang cukup tinggi menjadi daya tarik bagi nelayan untuk melakukan kegiatan penangkapan ikan. Tujuan penelitian ini adalah untuk menghitung tingkat pemanfaatan, nilai MSY dan JTB di perairan Dumai. Penelitian ini menggunakan data sekunder yaitu jumlah trip dan jumlah hasil tangkapan jaring insang, sondong dan pengerih sejak tahun 2014 hingga 2018. Nilai MSY dan upaya optimum dianalisis menggunakan model produksi surplus oleh Schaefer. Persamaan regresi antara upaya standar (f) dengan CPUE adalah $y=-0,00004 x+0,399$ dengan nilai $\mathrm{R}^{2}=0,9273$. Jumlah upaya optimum $\left(\mathrm{F}_{\mathrm{opt}}\right.$ ) adalah 4.604 trip/tahun dan nilai MSY sebesar 918,47 ton/tahun. Rata-rata tingkat pemanfaatan sumberdaya ikan mencapai $83 \%$ termasuk dalam kategori optimum. Nilai JTB ikan demersal sebesar 734,78 ton. Status pemanfaatan ikan demersal di perairan Dumai masuk kedalam kategori tangkap berlebih. Perlu ada pengaturan ulang mengenai upaya penangkapan (f) guna menjaga keberlanjutan sumber daya ikan dan kegiatan perikanan tangkap ikan demersal di Kota Dumai.
\end{abstract}

Kata kunci: CPUE, Dumai, ikan demersal, MSY

\begin{abstract}
Dumai City has small-scale capture fisheries fishermen who make demersal fish as the main target. Shallow water demersal fish resources were being the target of exploitation because they have a relatively high selling value and easy access. The aimed of this study was to calculate the utilization rate, MSY and total allowable catcth in the waters of Dumai. This study used secondary data, the number of trips and catches of gill nets, sondong and pengerih from 2014 to 2018. The MSY and optimal fishing effort were obtained used the surplus production model developed by Schaefer. The regression equation between standard fishing effort (f) and catch per unit effort (CPUE) is $y=-0,00004 x+$ 0,399 with $R 2=0.9273$. The maximum fishing effort (Fopt) was 4,604 trips/year and the MSY was 918.47 tons/year. The average utilization rate of fish resources reaches $83 \%$, which is included in the optimum category. The Total allowable catch was 734.78 tons. The status of the use of demersal fish in the waters of Dumai is overfishing. There needs to be a re-arrangement of fishing efforts (f) in order to maintain the sustainability of fish resources and demersal fishing activities in.
\end{abstract}

Key words: CPUE, Dumai, demersal fish, MSY

\section{PENDAHULUAN}

Dumai terletak diwilayah pesisir timur Pulau Sumatera, tepatnya di Provinsi Riau. Keberadaan wilayah perairan laut dimanfaatkan oleh pemerintah dan masyarakat setempat untuk sektor perikanan 
khususnya perikanan tangkap. Produksi perikanan tangkap memiliki sumbangsih hingga 90 persen dari produksi perikanan di Dumai. Perairan Dumai merupakan habitat yang sesuai bagi ikan demersal karena memiliki substrat pasir berlumpur (Sandria et al., 2014). Upaya penangkapan ikan demersal dilakukan menggunakan alat tangkap ikan demersal yang biasanya dioperasikan pada perairan dangkal (Badrudin dan Karyana, 1992). Nelayan tradisional yang melakukan upaya penangkapan ikan di Dumai beroperasi disepanjang pesisir Dumai hingga ke Selat Malaka (Firdaus et al., 2021).

Daerah penangkapan ikan demersal yang relatif mudah dan dekat untuk diakses serta memiliki milai ekonomis yang cukup tinggi menjadi daya tarik bagi nelayan untuk melakukan kegiatan penangkapan ikan (Noija et al., 2014). Nelayan penangkap ikan demersal di Dumai merasa terjadi penurunan ikan hasil tangkapan. Sumber daya ikan dapat dipulihkan tetapi terbatas maka perlu dilestarikan. Jika sumber daya ikan dimanfaatkan melampaui daya dukung ekosistemnya akan berdampak pada berkurangnya sumber daya tersebut sehingga menyebabkan penurunan produktifitas perikanan atau bahkan dapat menyebabkan kepunahan (Sajeri et al., 2019).

Tujuan penelitian ini adalah untuk menghitung tingkat pemanfaatan, nilai maksimum tangkap lestari (MSY) dan jumlah tangkapan ikan demersal yang diperbolehkan di perairan Dumai. Penelitian ini diharapkan dapat menjadi informasi awal dan referensi bagi para pemangku kebijakan pengelolaan sumberdaya ikan demersal di Dumai secara berkelanjutan.

\section{METODE PENELITIAN}

Penelitian ini dilaksanakan di perairan Dumai, Provinsi Riau dengan menggunakan data sekunder yaitu jumlah upaya atau effort dan jumlah hasil tangkapan jaring insang, sondong dan pengerih sejak tahun 2014 hingga 2018. Data sekunder yang digunakan pada penelitian ini merupakan data yang tercantum pada laporan tahunan Dinas Perikanan Kota Dumai. Data yang diperoleh selanjutnya dianalisis secara deskriptif. Adapun analisis data yang dilakukan pada penelitian ini adalah sebagai berikut:

Analisis Perhitungan CPUE dan Standarisasi Upaya

Hasil tangkapan per upaya penangkapan atau Catch per Unit Effort (CPUE) merupakan salah satu cara perhitungan untuk mengetahui kelimpahan dan tingkat pemanfaatan sumber daya perikanan. Jumlah hasil tangkapan atau produksi ikan dan upaya disusun berdasarkan tangkap terlebih dahulu, kemudian dilanjutkan dengan perhitungan CPUE. Upaya yang dimaksud dalam penelitian ini adalah jumlah trip penangkapan per alat tangkap. Perhitungan CPUE dilakukan dengan pendekatan (Sparre dan Venema, 1999) sebagai berikut:

$$
\text { CPUE }_{t}=\frac{\text { Catch }_{t}}{\text { Effort }_{t}}
$$

Keterangan:

$C P U E_{t}=$ CPUE tahun ke-t

Catch $_{t}=$ Produksi ikan tahun ke-t

Effort $_{t}=$ upaya penangkapan tahun ke-t

Alat tangkap ikan demersal yang dikaji pada penelitian ini adalah jaring insang, sondong dan pengerih yang digunakan oleh nelayan tradisional Dumai. Standarisasi alat tangkap perlu dilakukan karena kemampuan setiap tangkap berbeda. Standarisasi tersebut dimaksudkan untuk mendapatkan nilai total upaya rata-rata (total effort) sehingga dapat melakukan analisis ketahap selanjutnya (Fauzi dan Anna, 2005). Alat tangkap acuan untuk standarisasi adalah alat tangkap dengan produktivitas atau nilai CPUE tertinggi atau dengan indeks kemampuan tangkap atau Fishing Power Index (FPI) satu. Standarisasi dilakukan dengan persamaan sebagai berikut:

$$
E_{s t d}=\varphi_{n t} E_{n t}
$$


$\varphi_{n t}$ dihitung dengan membandingkan rasio CPUE dari suatu alat tangkap terhadap alat tangkap yang dijadikan standar pada periode waktu tertentu dengan persamaan sebagai berikut:

$$
\varphi_{n t}=\frac{U n_{t}}{U_{s t d}}
$$

Keterangan:

$E_{\text {std }} \quad=$ Upaya standar

$\varphi_{n t} \quad=$ FPI alat tangkap jenis ke $\mathrm{n}$ pada waktu $\mathrm{t}$

$E_{n t} \quad=$ Upaya alat tangkap ke-n pada waktu $\mathrm{t}$

$U_{n t} \quad=$ CPUE alat tangkap ke-n pada waktu $\mathrm{t}$

$U_{s t d} \quad=$ CPUE alat tangkap standar

Analisis Perhitungan MSY

Nila MSY sumberdaya ikan demersal dan upaya penangkapan optimal dihitung menggunakan model surplus produksi yang dikembangkan oleh Schaefer. Model tersebut adalah sebagai berikut:

$$
C P U E=a+b f
$$

Selanjutnya nilai a dan $\mathrm{b}$ dihitung dengan persamaan berikut:

$$
\begin{aligned}
& a=\frac{\left(\sum x_{i}\right)\left(\sum y_{i}\right)-\left(\sum x_{i}\right)\left(\sum x_{i} y_{i}\right)}{n\left(\sum x_{i}{ }^{2}\right)-\left(\sum x_{i}\right)^{2}} \\
& b=\frac{n\left(\sum x_{i} y_{i}\right)-\left(\sum x_{i}\right)\left(\sum y_{i}\right)}{n\left(\sum x_{i}{ }^{2}\right)-\left(\sum x_{i}\right)^{2}}
\end{aligned}
$$

Keterangan:

$$
\begin{array}{ll}
\mathrm{x} & =\text { Upaya penangkapan periode ke-i } \\
\mathrm{y} & =\text { CPUE periode ke- } \mathrm{i} \\
\mathrm{n} & =\text { Jumlah sampel }
\end{array}
$$

Hubungan antara upaya (f) dengan hasil tangkapan (C) maka:

$$
\begin{aligned}
& C=C P U E x f \\
& C=a f+b f^{2}
\end{aligned}
$$

kemudian upaya optimum (fopt) didapat dengan menyamakan turunan pertama hasil tangkapan terhadap upaya $=0$, sehingga

$$
\begin{aligned}
& C=a f+b f^{2} \\
& C=a-2 b f=0 \\
& f_{\text {opt }}=-\frac{a}{2 b}
\end{aligned}
$$

Nilai MSY dihitung berdasarkan persamaan berikut:

$$
\begin{aligned}
& M S Y=a\left(\frac{a}{2 b}\right)-b\left(-\frac{a^{2}}{4 b^{2}}\right) \\
& M S Y=-\frac{a^{2}}{4 b}
\end{aligned}
$$

Analisis Perhitungan Tingkat Pemanfaatan Sumberdaya Ikan

Tingkat pemanfaatan sumberdaya ikan dapat dihitung dengan membandingkan antara produksi pada periode tertentu dengan nilai MSY (Pauly, 1983). Persamaan tersebut adalah sebagai berikut:

$$
T P c=\frac{C i}{M S Y} \times 100 \%
$$

Keterangan: 
TPC = Tingkat pemanfaatan tahun ke-i (\%)

$\mathrm{Ci} \quad=$ Produksi tahun ke-i (ton)

MSY = Maximum Sustainable Yield (ton)

Analisis Perhitungan Jumlah Tangkapan yang Diperbolehkan (JTB)

JTB tertuang dalam Code of Conduct for Responsible Fisheries (CCRF) yang merupakan sebuah komitmen internasional bersama FAO menyebutkan bahwa potensi sumberdaya ikan di laut yang dapat dimanfaatkan sekitar 80\% dari Nilai MSY (Fitriana et al., 2017). Persamaan tersebut adalah sebagai berikut:

$$
J T B=80 \% \times M S Y
$$

\section{HASIL DAN PEMBAHASAN}

\section{Hasil Tangkapan per Upaya Penangkapan}

Berdasarkan Data Statistik Perikanan Kota Dumai Provinsi Riau tahun 2014-2018, alat tangkap yang digunakan oleh nelayan tradisonal di Dumai untuk menangkap ikan demersal adalah jaring insang, sondong dan pengerih (Tabel 1). Rata-rata hasil tangkapan selama periode 2014-2018 tertinggi dihasilkan oleh alat tangkap sondong sebanyak 338 ton, kemudian jaring insang 265 ton dan terakhir pengerih 163 ton. Rata-rata Upaya penangkapan terbanyak adalah pengerih sebanyak 8.424 trip, kemudian jaring insang 4.680 trip dan terakhir adalah sondong 2.430 ton. Pola produksi ikan demersal pada tahun 2014-2018 tampak berfluktuasi. Ketika alat tangkap tidak terkendali, sumber daya ikan berada di bawah tekanan (Huliselan et al., 2020). Nilai CPUE secara umum terjadi penurun pada seluruh alat tangkap. Hal tersebut dapat terjadi karena secara umum pada ketiga alat tersebut mengalami peningkatan upaya dan penurunan hasil tangkapan.

Nilai CPUE dan produksi yang cenderung menurun setiap tahunnya dan diikuti peningkatan upaya penangkapan mengindikasikan bahwa perairan Dumai masuk kedalam kategori tangkap berlebih (overfishing). Salah satu ciri overfishing adalah peningkatan upaya dan penurunan produksi dengan signifikan pada satuan waktu tertentu. Selain itu tangkap berlebih dapat terdeteksi dengan turunnya nilai CPUE dan Produksi (Lusi dan Ayunita, 2012).

Tabel 1. Produksi, upaya dan CPUE ikan demersal di perairan Dumai

\begin{tabular}{cccccccccc}
\hline & \multicolumn{3}{c}{ Produksi (ton) } & \multicolumn{3}{c}{ Upaya Penangkapan (trip) } & \multicolumn{3}{c}{ CPUE (ton/trip) } \\
\cline { 2 - 9 } Tahun & $\begin{array}{c}\text { jaring } \\
\text { insang }\end{array}$ & sondong & pengerih & $\begin{array}{c}\text { jaring } \\
\text { insang }\end{array}$ & sondong & pengerih & jaring & sondong & pengerih \\
\hline 2014 & 264,8 & 488,5 & 175,0 & 5.940 & 2.160 & 4.590 & 0,04 & 0,23 & 0,04 \\
2015 & 208,4 & 539,6 & 173,2 & 3.132 & 3.375 & 7.560 & 0,07 & 0,16 & 0,02 \\
2016 & 170,4 & 368,4 & 141,8 & 3.132 & 3.375 & 7.560 & 0,05 & 0,11 & 0,02 \\
2017 & 325,5 & 150,5 & 152,5 & 5.256 & 1.620 & 10.935 & 0,06 & 0,09 & 0,01 \\
2018 & 355,5 & 143,5 & 170,5 & 5.940 & 1.620 & 11.475 & 0,06 & 0,09 & 0,01 \\
\hline
\end{tabular}

Terdapat tiga alat tangkap yang dikaji pada penelitian ini. Standarisasi perlud ilakukan terhadap ketiga alat tangkap yang memiliki kemampuan berbeda-beda. Hal tersebut dilakukan untuk mendapatkan nilai total upaya rata-rata sehingga dapat dilakukan penjumlahan total effort (Fauzi dan Anna, 2005). Alat tangkap yang menjadi standar pada penelitian ini adalah Sondong. Hasil perhitungan standarisasi alat tangkap menunjukan bahwa upaya hasil standarisasi mengalami peningkatan sebesar 3.453 trip selama periode 2014-2018 (Tabel 2). 
Tabel 2. Standarisasi alat tangkap ikan demersal di perairan Dumai

\begin{tabular}{|c|c|c|c|c|c|c|c|}
\hline \multirow[t]{2}{*}{ Tahun } & \multicolumn{3}{|c|}{ Fishing Power Index } & \multicolumn{4}{|c|}{$\begin{array}{l}\text { Upaya Standar } \\
\text { (trip) }\end{array}$} \\
\hline & jaring insang & sondong & pengerih & jaring insang & sondong & pengerih & Total \\
\hline 2014 & 0,20 & 1,00 & 0,17 & 1171 & 2160 & 774 & 4105 \\
\hline 2015 & 0,42 & 1,00 & 0,14 & 1303 & 3375 & 1083 & 5762 \\
\hline 2016 & 0,50 & 1,00 & 0,17 & 1561 & 3375 & 1299 & 6235 \\
\hline 2017 & 0,67 & 1,00 & 0,15 & 3504 & 1620 & 1642 & 6765 \\
\hline 2018 & 0,68 & 1,00 & 0,17 & 4013 & 1620 & 1925 & 7558 \\
\hline
\end{tabular}

Regresi linier sederhana model surplus produksi Schaefer digunakan untuk mengetahui pengaruh dari jumlah upaya standar terhadap nilai CPUE (Sparre dan Venema, 1999)(Alwi et al., 2019). Berdasarkan hasil perhitungan didapatkan nilai a sebesar 0,399, b sebesar -0,00004, dan $\mathrm{R}^{2}$ sebesar 0,9273 (Gambar 1). Persamaan regresi antara jumlah upaya standar dengan nilai CPUE adalah $y=$ $-0,00004 x+0,399$. Upaya standar memiliki hubungan yang kuat ditunjukan dengan nilai koefisien korelasi 0,9273. Hal tersebut menunjukan bahwa variasi nilai CPUE dipengaruhi oleh nilai upaya standar sebesar 92,73\%. Peningkatan ataupun penurunan nilai CPUE dapat menggambarkan tingkat pemanfaatan sumberdaya ikan. Peningkatan nilai CPUE menunjukan bahwa penangkapan ikan masih dapat terus dikembangkan, nilai CPUE yang cenderung stagnan menunjukan penangkapan ikan mendekati titik jenuh usaha dan penurunan nilai CPUE menunjukan penangkapan ikan mengarah pada tangkap berlebih jika tidak dilakukan pengendalian (Suman et al., 2012). Baik peningkatan maupun penurunan nilai CPUE berpengaruh terhadap stok ikan di perairan (Nelwan et al., 2010).

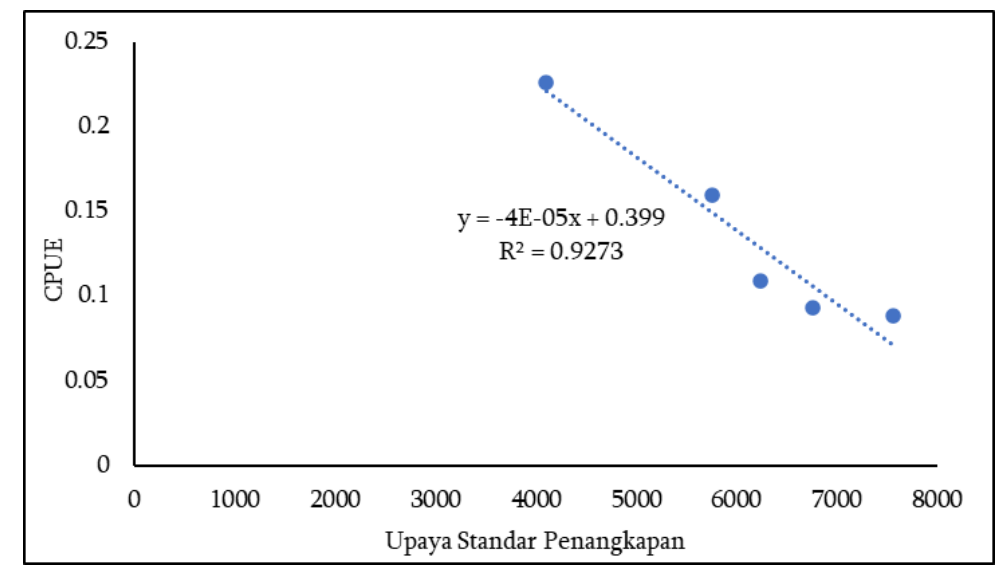

Gambar 1. Hubungan upaya standar dengan CPUE di perairan Dumai

\section{Nilai Maksimum Tangkap Lestari}

Nilai a dan $\mathrm{b}$ dari persamaan regresi digunakan untuk menghitung jumlah upaya optimum $\left(\mathrm{F}_{\mathrm{opt}}\right)$ dan nilai maksimum tangkap lestari (MSY). Berdasarkan perhitungan, didaptkan bahwa jumlah Fopt untuk ikan demersal adalah 4.604 trip/tahun dan nilai MSY ikan demersal sebesar 918,47 ton/tahun. Hal tersebut memberikan batasan jumlah upaya dan nilai MSY dengan tujuan menjaga kelestarian dan keberlanjutan sumberdaya ikan demersal serta terhindar dari masalah tangkap lebih. Manfaat lain Fopt adalah memperkecil kerugian bagi para pelaku usaha penangkapan khususnya nelayan tradisional dari segi waktu, tenaga dan biaya operasional sehingga sumberdaya ikan lesatari, produksi tetap tinggi dan tidak melampaui nilai MSY (Cahyani, 2013).

Menghitung nilai maksimum MSY guna menjaga jumlah populasi agar tetap optimum sehingga populasi tersebut tetap produktif dan dapat dimanfaatkan secara berkelanjutan (Hertini dan Gusriani, 2013). Berdasarkan grafik nilai MSY, hanya upaya pada tahun 2014 saja yang belum melampaui jumlah Fopt, sedangkan upaya tahun 2015 hingga 2018 sudah melampaui jumlah Fopt (Gambar 2). Jumlah upaya 
harus dikelola dan dikendalikan dengan baik, karena meskipun stok ikan berada dibawah nilai MSY tanpa ada pengelolaan dan pengendalian upaya dapat mengakibatkan terjadinya penuruan sumberdaya ikan (Yulianto et al., 2016).

Produksi ikan demersal di perairan Dumai secara umum telah melampaui nilai maksimum tangkap lestari (MSY). Grafik nilai maksimum tangkap lestari (MSY) menunjukan bahwa hasil tangkapan aktual tahun 2014, 2015 dan 2018 sudah melampaui nilai maksimum tangkap lestari (MSY), sedangkan tahun 2016 dan 107 masih di bawah nilai maksimum tangkap lestari (MSY). Hal tersebut sesuai dengan pernyataan yang menyebutkan bahwa kegiatan penangkapan di perairan Dumai dinilai kurang berkelanjutan, hal tersebut terlihat dari sisi ekologis maupun sosial ekonomi (Firdaus et al., 2021).

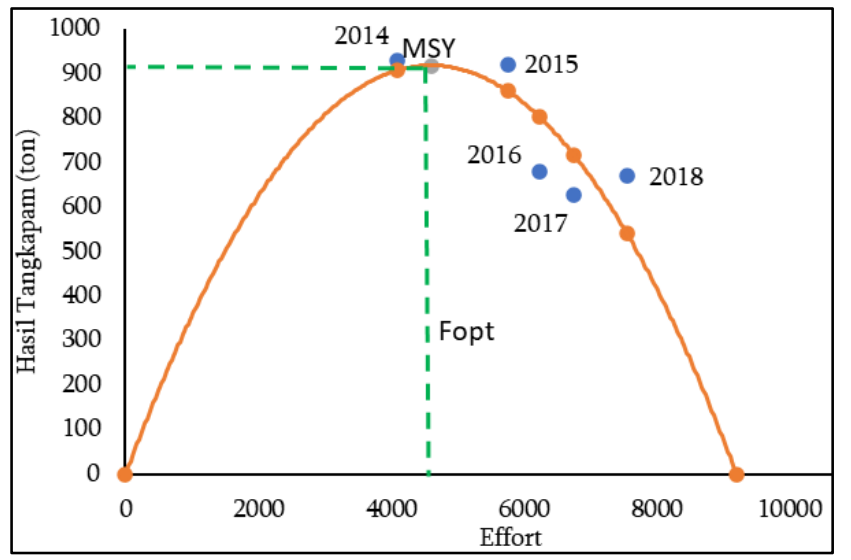

Gambar 2. Grafik nilai MSY ikan demersal di perairan Dumai

\section{Tingkat Pemanfaatan Sumberdaya Ikan Demersal}

Tingkat pemanfaatan sumberdaya ikan demersal tahun 2014 dan 2015 sudah mencapai nilai optimum. Tingkat pemanfaatan terendah terjadi tahun 2017 sebesar 68\%. Tingkat pemanfaatan sumberdaya ikan demersal di perairan Dumai selama periode 2014-2018 rata-rata mencapai 83\% (Gambar 3). Tingkat pemanfaatan secara optimum berkisar antara 66,6\% hingga 99,9\% dari nilai MSY (Fitriana et al., 2017). Berdasarkan hal tersebut, tingkat pemanfaatan sumberdaya ikan demersal di perairan Dumai selama periode 2014-2018 masuk dalam kategori optimum.

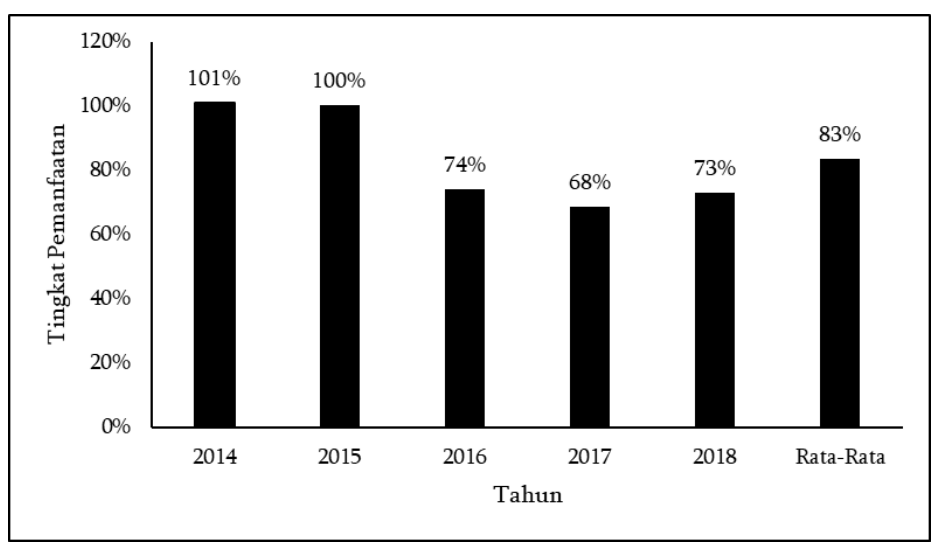

Gambar 3. Grafik tingkat pemanfaatan sumberdaya ikan demersal di perairan Dumai

\section{Jumlah Tangkapan yang Diperbolehkan}

Pendekatan kuota penangkapan ikan dengan memberlakukan pembatasan jumlah ikan yang boleh ditangkap merupakan upaya dalam melakukan pengelolaan sumberdaya ikan demersal. FAO 
telang mengatur JTB melalui CCRF bahwa potensi sumberdaya ikan di laut yang boleh dimanfaatkan hanya sekitar 80\% dari nilai MSY (Fitriana et al., 2017). Hasil penelitian menunjukan bahwa JTB sebesar 734,78 Ton. Nilai rata-rata hasil tangkapan pada periode 2014-2018 sebesar 766 ton. Hal tersebut menunjukan hasil tangkapan ikan demersal di perairan Kota dumai sudah melampaui JTB, sehingga dibutuhkan upaya pengelaloaan guna keberlanjutan sumberdaya ikan dan kegiatan perikanan tangkap ikan demersal di Kota Dumai.

\section{KESIMPULAN DAN SARAN}

Status pemanfaatan ikan demersal di perairan Kota Dumai masuk kedalam kategori tangkap berlebih. Hal tersebut ditinjau dari kecenderungan turunnya nilai CPUE, peningkatan upaya (f) yang jumlahnya telah melampau upaya optimum ( $f_{\text {opt }}$ ) sehingga menyebabkan nilai jumlah tangkapan aktual melebihi nilai MSY diikuti dengan hasil tangkapan rata-rata selama periode 2014-2018 telah melampaui jumlah tangkapan yang diperbolehkan (JTB). Perlu ada pengaturan ulang mengenai upaya (f) guna menjaga keberlanjutan sumber daya ikan dan kegiatan perikanan tangkap ikan demersal di Kota Dumai.

\section{UCAPAN TERIMA KASIH}

Terimakasih disampaikan kepada Dinas Perikanan Dumai dan Unit Pelayan Teknis (UPT) Pangkalan Pendaratan Ikan (PPI) Dumai yang telah berkenan memberikan dukungan berupa data yang dibutuhkan. Terimakasih juga disampaikan kepada Politeknik Kelautan dan Perikanan Dumai atas dana hibah penelitian ini dari skema Dana DIPA Politeknik Kelautan dan Perikanan Dumai.

\section{DAFTAR PUSTAKA}

Alwi, M. J., Abdullah, H., dan Aras, E. (2019). Status pemanfaatan Ikan Cakalang (Katsuwonus pelamis) di perairan Kabupaten Luwu Sulawesi Selatan. JOURNAL OF INDONESIAN TROPICAL FISHERIES, 2(2), 216-228. https://doi.org/10.33096/joint-fish.v2i2.55

Badrudin, dan Karyana. (1992). Indeks kelimpahan stok sumberdaya ikan demersal di perairan Barat Kalimantan. BPPL.

Cahyani, R. T. (2013). Kajian penggunaan cantrang terhadap kelestarian sumberdaya ikan demersal (analisis hasil tangkapan dominan yang didaratkan di TPI Wedung Demak). (Tesis). Universitas Diponegoro.

Fauzi, A., dan Anna, S. (2005). Pemodelan sumber daya perikanan dan lautan untuk analisis kebijakan. Gramedia Pustaka Utama.

Firdaus, A. M., Sari, S. P., dan Tampubolon, J. R. P. (2021). Kondisi perikanan tangkap di perairan Kota Dumai Provinsi Riau. Jurnal Marisland, 1(1), 1-12.

Fitriana, A., Zen, L. W., dan Susiana. (2017). Potensi dan tingkat pemanfaatan ikan demersal yang di daratkan pada Tempat Pendaratan Ikan (TPI) Desa Sebong Lagoi Kabupaten Bintan Kepulauan.

Hertini, E., dan Gusriani, N. (2013). Maximum ustainable yield (MSY) pada perikanan dengan struktur prey-predator. Seminar Nasional Sains Dan Teknologi Nuklir.

Huliselan, N. V., Sahetapy, D., Wawo, M., dan Tuapattinaya, M. A. (2020). Demersal fish resources utilization and socio-economic of fishermen in Kotania Bay, Western of Seram. Indonesia. IOP Conference Series: Earth and Environmental Science, 517(1). https://doi.org/10.1088/1755$1315 / 517 / 1 / 012010$ 
Lusi, A. N., dan Ayunita, D. (2012). Potensi dan tingkat pemanfaatan sumberdaya ikan demersal di perairan Kabupaten Pekalongan. Agriekonomika Jurnal Sosial Ekonomi Dan Kebijakan PertanianJurnal Sosial Ekonomi Dan Kebijakan Pertanian, 1(1), 1-14.

Nelwan, A. F. ., Sondita, M. F. ., Monintja, D. ., dan Simbolon, D. (2010). Evaluasi produksi perikanan tangkap pelagis kecil di perairan pantai barat Sulawesi Selatan. Maritek Jurnal Teknologi Perikanan dan Kelautan, 10(1), 41-51.

Noija, D., Martasuganda, S., Murdiyanto, B., dan Taurusman, A. A. (2014). Potensi dan tingkat pemanfaatan sumberdaya ikan demersal di Perairan Pulau Ambon Provinsi Maluku. Jurnal Teknologi Perikanan Dan Kelautan, 5(1), 55-64. https://doi.org/10.24319/jtpk.5.55-64

Pauly, D. (1983). Some sampel methods for the assessment of tropical fish stock. FAO fish Technical Paper.

Sajeri, H., Mustaruddin, dan Nurani, T. W. (2019). Utilization rate of demersal fish resources in Pangkep Regency South Sulawesi Indonesia. Australia and New Zealand Journal of Social $\begin{array}{llll}\text { Business, Environment } \quad \text { and } & \text { 5ustainability, }\end{array}$ https://www.researchgate.net/publication/337243774

Sandria, F., Fitri, A. D. P., dan Wijayanto, D. (2014). Analisis Potensi Dan Tingkat Pemanfaatan Sumberdaya Ikan Demersal Di Perairan Kabupaten Kendal. Journal of Fisheries Resources $\begin{array}{lllll}\text { Utilization Management and Technology, } & 3(3),\end{array}$ https://ejournal3.undip.ac.id/index.php/jfrumt/article/view/5231

Sparre, P., dan Venema, S. C. (1999). Introduksi pengkajian stok ikan tropis. FAO dan Pusat Penelitian dan Pengembangan Perikanan, Badan Penelitian dan Pengembangan Pertanian,.

Suman, A., Badruddin, M., dan Fauzi, M. (2012). Status Pemanfaatan Sumberdaya Ikan Pelagis Kecil di Perairan Teluk Tomini (WPP 716). Seminar Nasional Perikanan Tangkap.

Yulianto, G., Suwardi, K., Adrianto, L., dan Machfud, M. (2016). Status pengelolaan sumberdaya ikan demersal sekitar pantai di Kabupaten Indramayu Jawa Barat. Omni-Akuatika, 12(3), 1-10. https://doi.org/10.20884/1.oa.2016.12.3.113 